Annals of Plant and Soil Research 23(1): 108-111 (2021)

https://doi.org/10.47815/apsr.2021.10039

\title{
Influence of varieties and spacing on yield and quality of sprouting broccoli (Brassica oleracea L.)
}

\author{
PRADEEP KUMAR, SANJAY KUMAR, M.L. MEENA, RAJEEV KUMAR, RANJEET RAWAT AND \\ SHATRUNJAY YADAV
}

Department of Horticulture, Babasaheb Bhimrao Ambedkar University, Lucknow (U.P.)-226025

Received: September, 2020; Revised accepted: November, 2020

\begin{abstract}
A field experiment was undertaken at B.B.A. University, Lucknow (UP) during rabi season to study the effect of varieties and spacings on yield and quality characters of sprouting broccoli (Brassica oleracea $L$. var. italicaPlenck). Four varieties viz. $V_{1}$ - Pusa Broccoli KTS-1, $V_{2}$-Palam Kanchan, $V_{3}$-Palam Vichitra, $V_{4}$-Palam Samridhi and four spacings viz.- $S_{1}-60 \times 45 \mathrm{~cm}, S_{2}-60 \times 30 \mathrm{~cm}, S_{3}-45 \times 45 \mathrm{~cm}, S_{4}-45 \times 30 \mathrm{~cm}$ were evaluated in factorial randomized block design with three replications. Among the varieties, Pusa Broccoli KTS-1had takenearliest days for curd initiation (47.9) and day taken to curd harvest after curd initiation (22.5). VarietyPusa Broccoli KTS-1 significantly produced the highestcurd diameter $(118.9 \mathrm{~mm})$, weight of curd with gourd leaf $(0.9 \mathrm{~kg})$, weight of curd without gourd leaf $(0.4 \mathrm{~kg})$, yield $\left(24.5 \mathrm{tha}^{-1}\right)$, ascorbic acid $(79.1 \mathrm{mg} / 100 \mathrm{~g})$ and total soluble solids $\left(8.5^{\circ}\right.$ Brix). On the other hand, minimum values of these parameters were recorded in Pusa Samridhi. Spacing of $60 \times 45 \mathrm{~cm}$ took minimum days (48.9) for curd initiation, (22.5) and days taken to curd harvest after curd initiation. Maximum curd diameter $(116.8 \mathrm{~mm})$, weight of curd with gourd leaf $(0.9 \mathrm{~kg})$, weight of curd without gourd leaf $(0.4 \mathrm{~kg}$ ) were recorded in $60 \times 45 \mathrm{~cm}$ spacing. Quality parameters were also markedly affected with variety Pusa Broccoli KTS-1 and spacing $60 \times 45 \mathrm{~cm}$ and relatively higher value of vitamin C (79.9 $\mathrm{mg} / 100 \mathrm{~g})$ and total soluble solids $\left(8.8^{\circ}\right.$ Brix) were recorded under $V_{1} S_{1}$ treatment.
\end{abstract}

Keywords-Broccoli, varieties, spacing, yield, quality characters.

\section{INTRODUCTION}

Broccoli (Brassica oleracea var. italica), belongs to family cruciferae, is a member of Cole group having 18 chromosomes $(2 n=18, x=9)$. It is botanical classified as a variety of Brassica oleracea species, grown during cool-season for its green flowering head. Broccoli has large flower heads, usuallygreen in color, arranged in a tree-like structure on branches sprouting from a thick, edible stalk. Broccoli is a high-quality vegetable for fresh use and is one of the most popular frozen vegetables. It is highly nutritious crop containing high amount of vitamins ( $\mathrm{A}$ and $\mathrm{C})$ and minerals ( $\mathrm{K}, \mathrm{P}, \mathrm{Ca}$ and $\mathrm{Fe})$. Moreover, it also contains thiamine, riboflavin and niacin. Broccoli is the richest source of protein among cole crops. It is additionally a rich source of sulphoraphane, a compound related with decreasing the risk of cancer and also prevents heart disease. India is the second largest producer of broccoli after China, while the US ranks third. Growth, yield and quality of crop plant are mainlyinfluenced by two major factors viz. genotype and spacing. The existing varieties haveemerged mostly through selection from wide variability available. The improvement in the crop is mainly achieved through selection and evaluation. For successful cultivationof any crop in any area, the identification of suitable varietiesis of prime importance (Bhagare et al. 2011). Optimum plant spacing is one of the important factors in increasing the yield and quality of crops (Singh et al. 2006, Yadav et al. 2016). Therefore, present studies were aimed at promotion of high valued broccoli by identifying and standardization of optimum plant spacing to obtain better growth, yield and quality of broccoli inLucknow region. There is no any recommendation has been available with respect to suitability of specific variety for certain region. Therefore it is necessary to make a certain recommendations to generate research evidences with respect to suitability of certain varieties in a specific season to benefit the growers of Lucknow region.

\section{MATERIALS AND METHODS}

The field experiment was conducted at BabasahebBhimraoAmbedkar University, Lucknow (UP), during rabi season of 2017-18 
and 2018-19.The experimental site is situated at $26^{\circ} 50^{\prime} \mathrm{N}$ latitude, $80^{\circ} 52^{\prime} \mathrm{E}$ longitude and altitude of 111 meter above mean sea level (MSL). The area experiences rainfall from April to October with many rains from June to early September. The area receives average rainfall between 800 and $1000 \mathrm{~mm}$ with temperature ranging from 15 to $30^{\circ} \mathrm{C}$. Transplanting was done when the seedlings were 30 days old on $24^{\text {th }}$ Nov.2017 and 26thNov.2018 in first and second year, respectively.Four varieties viz. $\mathrm{V}_{\mathbf{1}}$ - Pusa Broccoli KTS-1, $V_{2}$-Palam Kanchan, $\mathrm{V}_{3}$-Palam Vichitra , $\mathrm{V}_{4}$-Palam Samridhi with four spacings viz.- $S_{1}$ $60 \times 45 \mathrm{~cm}, \mathrm{~S}_{2}-60 \times 30 \mathrm{~cm}, \mathrm{~S}_{3}-45 \times 45 \mathrm{~cm}, \mathrm{~S}_{4}-$ $45 \times 30$ cmwere evaluated in factorial randomized block design with three replication. The soil of the experimental site was sandy loam in texture having $\mathrm{pH}$ of 7.9 , organic carbon $4.2 \mathrm{~g}$ $\mathrm{kg}^{-1}$, available $\mathrm{N}, \mathrm{P}$ and $\mathrm{K}$ content 200,12 and $185 \mathrm{~kg} \mathrm{ha}^{-1}$, respectively. Recommended dose of $\mathrm{N}, \mathrm{P}_{2} \mathrm{O}_{5}$ and $\mathrm{K}_{2} \mathrm{O}$ was supplied through urea, single super phosphate and muriate of potash, respectively. FYM was applied 20 days before transplanting. The crop was grown with standard agronomic practices and plant protection measures were adopted as per schedule. The observations were recorded on yield and quality characters viz.-curd initiation day, day taken to curd harvest after curd initiation, curd diameter, weight of curd with gourd leaf, weight of curd without gourd leaf, yield, total solube solids, total sugar, reducing and non reducing sugar were determined as per methods adopted by Ranganna (1977). The data were statistically analysed as per procedure of Panse and Sukhatme (1978).

\section{RESULTS AND DISCUSSION}

\section{Varieties}

Results revealed that all the varieties of broccoli exhibited significant variation in their performance in terms of yield attributes and quality characters. Among the genotypes, Pusa Broccoli KTS-1 recorded the minimum

Table 1: Influence of varieties and spacing's on yield attributing and yield of sprouting broccoli

\begin{tabular}{|c|c|c|c|c|c|c|}
\hline Treatment & $\begin{array}{c}\text { Curd } \\
\text { initiation } \\
\text { days }\end{array}$ & $\begin{array}{l}\text { Day taken to curd } \\
\text { harvest after curd } \\
\text { initiation }\end{array}$ & $\begin{array}{l}\text { Curd } \\
\text { diameter } \\
(\mathrm{mm})\end{array}$ & $\begin{array}{l}\text { Weight of curd } \\
\text { with gourd leaf } \\
(\mathrm{kg})\end{array}$ & $\begin{array}{l}\text { Weight of curd } \\
\text { without gourd } \\
\text { leaf }(\mathrm{kg})\end{array}$ & $\begin{array}{l}\text { Yield } \\
\left(\mathrm{t} \mathrm{ha} \mathrm{C}^{-1}\right)\end{array}$ \\
\hline \multicolumn{7}{|c|}{ 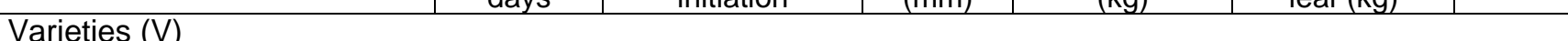 } \\
\hline $\mathrm{V}_{1}$ (Pusa Broccoli KTS-1) & 47.9 & 22.5 & 118.9 & 0.9 & 0.4 & 24.5 \\
\hline $\mathrm{V}_{2}$ (PalamKanchan) & 48.5 & 22.9 & 114.1 & 0.9 & 0.4 & 23.5 \\
\hline $\mathrm{V}_{3}$ (PalanVichitra) & 52.5 & 24.2 & 115.8 & 0.9 & 0.4 & 24.2 \\
\hline $\mathrm{V}_{4}$ (PalamSamridhi) & 50.6 & 22.9 & 109.1 & 0.8 & 0.4 & 23.2 \\
\hline \multirow{2}{*}{\multicolumn{7}{|c|}{ Spacing $(S)$}} \\
\hline & & & & & & \\
\hline $\mathrm{S}_{1}(60 \times 45 \mathrm{~cm})$ & 48.9 & 22.5 & 116.8 & 0.9 & 0.4 & 17.9 \\
\hline $\mathrm{S}_{2}(60 \times 30 \mathrm{~cm})$ & 49.5 & 23.0 & 116.2 & 0.9 & 0.4 & 26.0 \\
\hline $\mathrm{S}_{3}(45 \times 45 \mathrm{~cm})$ & 50.2 & 23.6 & 114.3 & 0.8 & 0.4 & 21.8 \\
\hline $\mathrm{S}_{4}(45 \times 30 \mathrm{~cm})$ & 51.0 & 24.1 & 111.3 & 0.8 & 0.4 & 29.7 \\
\hline $\mathrm{CD}(\mathrm{P}=0.05)$ & 2.27 & 0.34 & 1.39 & 0.08 & 0.01 & 0.04 \\
\hline \multicolumn{7}{|l|}{ (Interaction) (VxS) } \\
\hline $\mathrm{V}_{1} \mathrm{~S}_{1}$ & 46.4 & 21.5 & 121.1 & 1.0 & 0.5 & 18.5 \\
\hline $\mathrm{V}_{1} \mathrm{~S}_{2}$ & 47.4 & 22.2 & 120.6 & 1.0 & 0.4 & 27.2 \\
\hline$V_{1} S_{3}$ & 48.6 & 23.2 & 116.4 & 0.9 & 0.4 & 22.1 \\
\hline $\mathrm{V}_{1} \mathrm{~S}_{4}$ & 49.1 & 23.4 & 117.5 & 0.8 & 0.4 & 30.3 \\
\hline $\mathrm{V}_{2} \mathrm{~S}_{1}$ & 47.5 & 22.5 & 117.8 & 0.9 & 0.4 & 17.6 \\
\hline $\mathrm{V}_{2} \mathrm{~S}_{2}$ & 48.0 & 23.0 & 116.9 & 0.9 & 0.4 & 25.3 \\
\hline $\mathrm{V}_{2} \mathrm{~S}_{3}$ & 48.6 & 23.1 & 113.2 & 0.8 & 0.4 & 21.3 \\
\hline $\mathrm{V}_{2} \mathrm{~S}_{4}$ & 49.9 & 23.9 & 108.6 & 0.8 & 0.4 & 29.7 \\
\hline $\mathrm{V}_{3} \mathrm{~S}_{1}$ & 51.9 & 23.0 & 118.7 & 1.0 & 0.4 & 18.1 \\
\hline$V_{3} S_{2}$ & 52.3 & 23.8 & 117.6 & 0.9 & 0.4 & 25.9 \\
\hline$V_{3} S_{3}$ & 52.7 & 24.7 & 115.7 & 0.9 & 0.4 & 22.7 \\
\hline $\mathrm{V}_{3} \mathrm{~S}_{4}$ & 53.1 & 25.2 & 111.2 & 0.8 & 0.4 & 30.1 \\
\hline $\mathrm{V}_{4} \mathrm{~S}_{1}$ & 49.9 & 22.5 & 110.3 & 0.9 & 0.4 & 17.3 \\
\hline $\mathrm{V}_{4} \mathrm{~S}_{2}$ & 50.1 & 23.0 & 109.7 & 0.9 & 0.4 & 25.6 \\
\hline$V_{4} S_{3}$ & 50.6 & 23.2 & 109.0 & 0.8 & 0.4 & 21.2 \\
\hline $\mathrm{V}_{4} \mathrm{~S}_{4}$ & 51.8 & 23.6 & 108.0 & 0.8 & 0.3 & 28.7 \\
\hline$C D(P=0.05)$ & 4.54 & 0.68 & 2.78 & 0.16 & NS & 0.24 \\
\hline
\end{tabular}


days (47.9) for curd initiation, (22.4) days taken to curd harvest after curd initiation and maximum days were taken by PalamVichitra for these two yield attributes. The maximum curd diameter (118.9 mm), weight of curd with gourd leaf $(0.9$ $\mathrm{kg})$, weight of curd without gourd leaf $(0.4 \mathrm{~kg})$ and curd yield (24.5 t ha-1)were recorded with Pusa Broccoli KTS-1 variety. These results are in close conformity with the results of Bhangre et al.(2011). Pusa KTS-1performed better over the cv. PalamKanchan. On the other hand minimum values of these parameters were recorded with PalamSamridhi. The curd of Pusa Broccoli KTS1 contained relatively high amount of vitamin $\mathrm{C}$ $(79.1 \mathrm{mg} / 100 \mathrm{~g})$ and total soluble solids $\left(8.5^{\circ}\right.$ Brix) while higher values of total sugar $(3.9 \%)$, reducing sugar ( $3.3 \%$ ) and non-reducing sugar $(0.7 \%)$ were recorded in curd of PalamVichitra.These finding are in close conformity with Singhal et al. (2009).

\section{Spacing}

The data (Table 1 and 2) showed that yield and quality parameters were significantly affected with spacings. The spacing of $60 \times 45 \mathrm{~cm}$ took minimum days (48.9) for curd initiation and days taken to curd harvest after curd initiation (22.5). Maximum curd diameter (116.8 mm), weight of curd with gourd leaf $(0.9 \mathrm{~kg})$, weight of curd without gourd leaf $(0.4 \mathrm{~kg})$ was recorded in $60 \times 45 \mathrm{~cm}$. On the other hand, maximum curd yield $\left(29.7 \mathrm{t} \mathrm{ha}^{-1}\right)$ was recorded will $45 \times 30 \mathrm{~cm}$ spacing.These results are close conformity with the results ofSolunkeet al. (2011) and Khetan et al. (2016). The maximum yield per plot was found recorded at higher plant density which was possibly due to more number of plants per unit area; higher ground covers of leaf area resulted in higher light interception and hence, higher assimilate production. Similar results have been reported by Agarwalet al. (2007), Khatan et al. (2016) and Gogoi et al. (2016) in broccoli. Quality parameters were also significantly affected with spacing. The maximum value of vitamin $C(79.1 \mathrm{mg} / 100 \mathrm{~g})$ and total soluble solids $\left(8.3^{\circ} \mathrm{Brix}\right)$ were recorded with $60 \times 45 \mathrm{~cm}$ spacing.While total sugar (3.8\%), reducing sugar $(3.3 \%)$ and non-reducing sugar $(0.6 \%)$ were recorded maximum in $60 \times 30 \mathrm{~cm}$ spacing (Vinod sutar et al. 2017).

Table 2: Influence of varieties and spacing's on yieldand quality characters of sprouting broccoli

\begin{tabular}{|c|c|c|c|c|c|}
\hline \multirow[b]{2}{*}{ Treatment } & \multicolumn{5}{|c|}{ Yield and yield attributing characters } \\
\hline & $\begin{array}{l}\text { Vitamin-C } \\
(\mathrm{mg} / 100 \mathrm{~g})\end{array}$ & $\begin{array}{l}\text { Total soluble } \\
\text { solids ('Brix) }\end{array}$ & $\begin{array}{c}\text { Total sugars } \\
(\%)\end{array}$ & $\begin{array}{l}\text { Reducing } \\
\text { sugar (\%) }\end{array}$ & $\begin{array}{c}\text { Non-reducing } \\
\text { sugar }\end{array}$ \\
\hline \multicolumn{6}{|l|}{ Varieties $(\mathrm{V})$} \\
\hline$V_{1}$ (Pusa Broccoli KTS-1) & 79.1 & 8.5 & 3.8 & 3.2 & 0.6 \\
\hline$V_{2}$ (PalamKanchan) & 78.2 & 8.2 & 3.7 & 3.2 & 0.5 \\
\hline $\mathrm{V}_{3}$ (PalanVichitra) & 78.0 & 7.9 & 3.9 & 3.3 & 0.7 \\
\hline$V_{4}$ (PalamSamridhi) & 78.3 & 8.0 & 3.8 & 3.3 & 0.6 \\
\hline $\mathrm{SCD}_{5 \%}$ & 1.00 & 1.03 & NS & NS & 0.11 \\
\hline \multicolumn{6}{|l|}{ Spacing (S) } \\
\hline$S_{1}(60 \times 45 \mathrm{~cm})$ & 79.1 & 8.3 & 3.8 & 3.2 & 0.5 \\
\hline $\mathrm{S}_{2}(60 \times 30 \mathrm{~cm})$ & 78.9 & 8.2 & 3.8 & 3.3 & 0.6 \\
\hline $\mathrm{S}_{3}(45 \times 45 \mathrm{~cm})$ & 78.1 & 8.1 & 3.8 & 3.3 & 0.6 \\
\hline $\mathrm{S}_{4}(45 \times 30 \mathrm{~cm})$ & 77.5 & 7.9 & 3.8 & 3.2 & 0.5 \\
\hline $\mathrm{CD}_{5 \%}$ & 1.00 & 1.03 & NS & NS & 0.11 \\
\hline
\end{tabular}

\section{Interaction}

Data (Table 1, 2\&3) revealed that yields were significantly affected with interaction. Among the interaction, $V_{1} S_{1}$ recorded the minimum days (46.4) for curd initiation, days taken to curd harvest after curd initiation (21.5 days). The maximum curd diameter $(121.1 \mathrm{~mm})$, weight of curd with gourd leaf $(1.0 \mathrm{~kg})$, weight of curd without gourd leaf $(0.5 \mathrm{~kg})$ were recorded under $\mathrm{V}_{1} \mathrm{~S}_{1}$ treatment. The maximum curd yield $\left(30.3 \mathrm{t} \mathrm{ha}^{-1}\right)$ was recorded in $\mathrm{V}_{1} \mathrm{~S}_{4}$ treatment.These results are in close conformity with the findings of Bhangreet al. (2011) and Gariya et al. (2016). Quality parameters were also significantly affected with varieties and spacing's interaction and $\mathrm{V}_{1} \mathrm{~S}_{1}$ recorded relatively high value of vitamin $C(79.9 \mathrm{mg} / 100 \mathrm{~g})$. These findings were in close conformity withthose ofSinghalet al. (2009). 
It may be concluded from the results that the varieties and spacings showed significant variation among the different parameters. When the distance between plants increased, the quality related parameters were also increased.

\section{REFERENCES}

Agarwal, A., Gupta, S. and Ahmed, Z. (2007) Nitrogen nutrition and plant density influencingmarketable head yield of broccoli in cold arid desert of Ladakh. Acta Horticulture 756: 299 -307.

Bhangre, K. K., Sonawane, P.C. and Warade, S.D. (2011) Effect of different varieties and spacing on growth and yield parameters of broccoli (Brassica oleraceaL. var. Italica Plenck) under Pune conditions. Asian Journal of Horticultures 80(1): 52-56.

Gariya, M.S., Bhatt, L., Uniya, S.P. andMaurya.S.K. (2016)Optimization of planting geometry and water requirement through drip irrigation in sprouting broccoli. Research Crops 17(3): 562-567.

Gogoi, S., Millu, R., Das, P., Bora, N. and Das, B. K. (2016) Effect of sowing dates and spacing on broccoli (Brassica oleracea var. italica) seed production. Indian Journal of Agricultural Research 50(4):350-353.

Khatun, K., Saha, S.R. and Mostrain, T. (2016) Growth and yield of broccoli as influenced by plant spacing. International Journal of sustainable Agricultural Technology 7(12):7-12.

Panse, V.G. and Sukhatme, P.V. (1978) Statistical methods for agricultural
Generally, the wider the plant spacing the better is the performance of the broccoli. Thus, variety Pusa Broccoli KTS-1 and spacing $60 \times 45 \mathrm{~cm}$ ) and their interaction significantly affected that yield attributes and yield of broccoli.

workers.Indian council of agricultural research, New Delhi 3(24): 357-358.

Ranganna, S. (1977) Mannual of Analysis of fruits and vegetable products. Tata Mc Graw Hill, New Delhi

Singh, R., Chaurasia, S.N.S. and Singh, N.S. (2006) Response of nutrient sources and spacing on growth and yield of broccoli. (Brassica oleraceavar. italicaplenck). Vegetable Science 33(2): 198-200.

Singhal, P., Srivastava, B.K., Singh, M.P. and Singh, P.K. (2009)Effect of date of planting and spacing on the performance of broccoli. Indian Journal of Horticulture 66(1): 137-140.

Solunke, B.G., Wagh, A.P., Dod, V.N. and Nagre, P.K. (2011) Effect of dates of planting and spacing on growth and yield of broccoli. Asian Journal of Horticulture 6(2): 294-296.

Vinodsutar,Aravindakshan, K. and Bola, P.K. (2017) Effect of sowing date and spacing on growth, yield and quality of broccoli (Brassica oleracea var. italica) cultivar.Green head.Chemical science review and letters 6(21): 209-212.

Yadav, L.P., Singh, A. and Malhotra, S.K. (2016) Growth, yield and quality response of organic broccoli to intercrops and crop geometry. Indian Journal of horticulture 73(3): 376-382. 